\title{
Macro and micropolitics recontextualization of an integrated curriculum: experienced itinerary in nursing undergraduate ${ }^{a}$
}

\author{
Recontextualização macro e micropolítica do currículo integrado: percursos experimentados em um \\ curso de enfermagem
}

\author{
Nueva contextualización macro y micropolitica del currículo integrado: los caminos experimentados \\ en un curso de enfermeira
}

\author{
Elaine Cristina Dias Franco ${ }^{1}$ (D) \\ Amanda Nathale Soares ${ }^{2}$ (iD) \\ Maria Flávia Gazzinelli ${ }^{3}$ (iD
}

1. Universidade Federal de São João del Rei. Divinópolis, MG, Brasil.

2. Escola de Saúde Pública do Estado de Minas Gerais. Belo Horizonte, MG, Brasil. 3. Universidade Federal de Minas Gerais. Belo Horizonte, MG, Brasil.
Corresponding author:

Elaine Cristina Dias Franco.

E-mail: elainefranco@ufsj.edu.br

Submitted on $02 / 20 / 2018$

Accepted on 05/29/2018.

DOI: 10.1590/2177-9465-EAN-2018-0053

\begin{abstract}
Aim: To analyze the process of recontextualization of an integrated curriculum of Nursing Undergraduate Program. Method: Qualitative research, of a single case study, developed through documentary analysis, systematic observation and a semi-structured interview with nine teachers. Analysis of data by Critical Discourse Analysis. Results: The process of recontextualizing an integrated curriculum in the contexts of the Policy Cycle reveals that, in the Context of Influence and Textual Production, the curriculum is the result of a bricolage of educational policies, health policies and experiences of other institutions. Conclusion: Fragilities related to the organization of the modular structure and the teacher's close approximation to the Textual Production Context of the curriculum, associated to the training experience, favor the recontextualization of the curricular proposal when it is translated into the Context of Practice. It is necessary to institute strategies that integrate teacher education into their daily lives in curricular policies.
\end{abstract}

Keywords: Nursing; Education higher; Curriculum; Faculty, Nursing; Education, Nursing.

\section{REsUmo}

Objetivo: Analisar o processo de recontextualização do currículo integrado de um Curso de Graduação em Enfermagem. Método: Pesquisa qualitativa, do tipo estudo de caso único, desenvolvido por meio de análise documental, observação sistemática e entrevista semiestruturada com nove docentes. Análise dos dados pela Análise Crítica do Discurso. Resultados: O processo de recontextualização do currículo integrado nos contextos do Ciclo de Políticas revela que, no Contexto da Influência e da Produção Textual, o currículo é resultado de uma bricolagem de políticas educacionais, políticas de saúde e experiências de outras instituições. Conclusão: Fragilidades relacionadas à organização da estrutura modular e à pouca aproximação do docente com - Contexto da Produção Textual do currículo, associadas à formação e à experiência docente, favorecem a recontextualização da proposta curricular quando é traduzida para o Contexto da Prática. É necessário instituir estratégias que integrem a formação docente aos seus cotidianos nas políticas curriculares.

Palavras-chave: Enfermagem; Ensino superior; Currículo; Docentes de Enfermagem; Educação em Enfermagem.

\section{Resumen}

Objetivo: Analizar el proceso de una nueva contextualización del currículo integrado de un Curso de Pregrado en Enfermería. Método: Investigación cualitativa, del tipo estudio de caso único, desarrollado por medio de análisis documental, observación sistemática y entrevista semiestructurada con nueve docentes. Análisis de los datos por el Análisis Crítico del Discurso. Resultados: El proceso para una nueva contextualización del currículo integrado en los contextos del Ciclo de Políticas revela que el currículo es el resultado de un bricolaje de políticas educativas, políticas de salud y experiencias de otras instituciones. Conclusión: Las fragilidades relacionadas con la organización de la estructura modular y la poca aproximación del docente con el Contexto de la Producción Textual del currículo favorecen una nueva contextualización de la propuesta curricular cuando se traduce al Contexto de la Práctica. Es necesario instituir estrategias que integren la formación docente a sus cotidianos en las políticas curriculares.

Palabras clave: Enfermería; Educación Superior; Currículo; Docentes de Enfermería; Educación en Enfermería. 


\section{INTRODUCTION}

In the last decades, transformations experienced by society have been putting education not only as a condition for access to a Professional training, but as an space to train individuals with skills to adapt themselves to Constant variation on global society. This brings repercusions to the ways of operating education. ${ }^{1,2}$

The emergence of a new modus operandi for education brings to the fore the international agencies that set guidelines for teaching in the 21st century. On these guidelines, it is attributed to education the mission to contribute to the development of the individual and the society and puts on schedule the need of curricular proposals that overcome fragmented teaching and specialization, in order to meet market needs of work and society. ${ }^{3,4}$

As measure to meet redirecting curricular policies, integrated curriculum is then caught as a favorable proposal to training aimed by contemporary society. ${ }^{5,6}$ In Brazil, higher education, the redirecting of educational policies have happened through National Curricular Guidelines (NCG).

NCG, when indicating the path to vocational training and giving autonomy and flexibility to the organization of the programs, point out the need for changes in the training process in the health area, ${ }^{7}$ putting on schedule curricular integration. ${ }^{5,8,9}$ In the scope of the training of professionals for the health area, in 2001, the Curricular Guidelines for Nursing (NCG/ENF) undergraduate programs were instituted, among others, ${ }^{10}$ that, associated to health policies, have been the guiding thread of the discussions and (re) formulations of curricula of Nursing Undergraduate Programs since the early years of the 2000s, ${ }^{11}$ directing, including, for integrated proposals of curriculum. ${ }^{12-15}$

Training through an integrated curriculum in the health area has been increasingly frequent. It's potentialities have been pointed out in some studies, with emphasis on overcoming the dichotomy between theory and practice; teaching based on contextualization and problematization; and the diversification of teaching scenarios. ${ }^{16-20}$ However, there are also challenges on implementing integrated curricula, as the difficulty to adhere NCG, the little proximity of professors with the Pedagogical Project of the Course (PPC) and the pedagogical unpreparediness to operate them. ${ }^{18-20}$

It is understood that curricular policies are processes of complex negociation associated to laws, guidelines, curricular documents and to the curriculum put into practice by teachers from their referentials and their Professional experiences. ${ }^{21}$ Association of macropolitic elements (educational policies, guidelines, among others) and micropolitic (pedagogical projects, teaching practice) involved on curricular policies compose a cycle of contexts of educational policies production called Cycle of Policies.

For the authors that propose Cycle of Policies, ${ }^{21}$ curricular policies are (re)interpreted within three interrelated contexts: Influence Context, in which, through multilateral organizations and national guidelines, are instituted political discourse that will be assumed by subjects that produce educational politics; o Context of Textual Production, in which political discourses produced in the Influence Context become a way political texts represented on educational and curricular policies that are proposed by teaching institutions; and Pratice Context, that conditutes the translation of curricular text into practice, being scenery in which the curricular policy is subject to interpretation and recreation that can represent change on original policy. ${ }^{21}$

On higher education, few studies ${ }^{19,22}$ that used the Cycle of Policies to analyze the implementation of educational policies reveal that higher education institutions do not reproduce them mechanically, but recontextualize them in the implementation of the curricular policies of their courses, according to their institutional reality. Recontextualization, according to Bernstein, is the displacement of curricular texts/discourses from their original context from (re)interpretations and (re)significations done by social actors involved. ${ }^{23}$

Considering contexts of production of curricular policies and projects of recontextualization that occur on and among these contexts, in this reearch as object of the Integrated Curriculum of an undergraduate course of Nursing. It is adopted as a assumption that instituted movements by teachers for elaboration of integrated curriculum on interlacing Influence and Textual Production Contexts and for it's translation to the Practice Context are mediated through recontextualization processes that institute new paths for the curricular proposal. Discourses and reasons on which the new senses given to the integrated curriculum are based are also highlighted, as well as the resistances and the changes that generate conflicts in the process of this process.

With the aim of analyzing the process of recontextualization of integrated curriculum of an undergraduate course in Nursing, this research differs from most current productions on nursing curricula by bringing to light aspects that involve the (re)production of curricular policies and the assemblages of the various social actors (multilateral agencies, institutional managers and teachers) in the daily routine of the integrated curriculum. It enables the unveil that compses recontextualization of elements from macro and micropolitics that sustain a curricular policy.

\section{METHOD}

Qualitative research, of the single case study type, ${ }^{24}$ that enabled profund analysis, with emphasis on interpretation and amplified retraction, of recontextualization processes of the integrated curriculum of the Nursing Undergraduate Program. The case studied was the undergraduate Nursing program of a Higher Education Institution, located in Minas Gerais, which adopts as curriculum policy the integrated curriculum, which was elaborated in 2008 and implemented in 2009. It's origin has as a start point of substitution of a curriculum organized through Problem Based Learning (PBL) proposed initially by the institution. For the elaboration of the integrated curriculum, the 
professors counted on technical visits and external assistance. The integrated curriculum, based on the principles of the relation theory and practice, teaching-service-community integration and interdisciplinarity, is organized in curricular units that are integrated through a modular structure.

The analysis of recontextualization processes of the investigated curriculum was given in the light of Sthepen Ball and Richard Bowe's Cycle of Policies Approach and Recontextualization Theory by Basil Bernstein. The Cycle of Policies Approach is an analytical theoretical framework, ${ }^{21}$ which, associated to Recontextualization Theory, ${ }^{23}$ enables analysis of processes that permeate (re)interpretation and (re)signification of educational policies in macro and micropolitical contexts.

The study participants were nine teachers, of whom two were selected because they were the first teachers to compose the Nursing Undergraduate Program and because they had experienced the structuring of the campus and the management of the course. The other teachers were chosen for lecturing in the curricular unit Practice of Teaching, Service and Community Integration (PTSCI), considered the main curriculum for integration of different areas of knowledge and teching-servicecommunity. PTSCl is configured as a teaching and learning space based on problematization and interdisciplinarity. It has as orientation the cycle of life and it's developed, from the $1^{\text {st }}$ to the $7^{\text {th }}$ period of course, in public health services of different complexity and areas. In this curricular unit, students are divided into groups of 5 to 10 students, according to the complexity of the health services.

For teacher's selection, there was following criteria: to be an effective lecturer in the Nursing Undergraduate Program; have a performance in the minimum PTSCl of twelve months, period considered adequate for the understanding of the PTSCl; and be willing to participate in the two stages of the study - observation of teaching practice in the PTSCl and semi-structured interview. The choice of the number of teachers had as criterion to guarantee the representation of all the periods in which the PTSCI unit happens, being, therefore, a teacher of each period.

Data were collected between may and september 2014 through systematic observation, semi-structured interviews and documentary analysis. Systematic observation was related to teaching practice at the PTSCI. Seven classes were observed, one from each period of the course, corresponding to the observation of a complete class shift in each selected PTSCI group. Observations were developed by the researcher using a semistructured guidecomposed by field identification, teacher's name, observed class, activities proposal for the day and description of the teacher's practice conduct. Observations were recorded in audio, registered in field notes, according the semi-structured guide, and, afterwards, notes of observation produced, that were coded with the initials PTSCI followed by two random letter from the alphabet defined by the researcher (exemple, PTSCI SB).

The semi-structured interview was carried out with the nine selected teachers. Participants received the P-coding followed by the order of the interviews. The interviews lasted an average of twenty minutes and were recorded in audio. For the documentary analysis phase, the PPC and the Institutional Development Plan (IDP), associated with the National Curricular Guidelines for Nursing graduation and international policies, were considered, such as the UNESCO Guidelines for Higher Education in the 21st Century. In this phase, it was sought to identify in the text of the PPC, associated with the IDP, elements that characterize the educational guidelines of national and international agencies that direct higher education.

The analysis of empirical data happened through Critical Discourse Analysis proposed by Norman Fairclough, who understands that discourse constitutes society and is constituted by society. ${ }^{25}$ This study was approved by the Research Ethics Committee of the responsible institution, with Certificate of Presentation for Ethical Assessment (CAAE) no 25962314.7.00005149, feedback $\mathrm{n}^{\circ}$ 1901547, in compliance with the ethical aspects set forth in Resolution 466/2012.

\section{RESULTS}

Consonant to the refential Cycle de Policies, empirical data from the interviews, observation and documentary analysis are presented here in two analytical categories: (I) The construction of the curricular proposal and Influence and Textual Production Contexts; and (II) Practice Context: recontextualization from the curriculum for teaching practice.

\section{The construction of the curricular proposal and Influence and Textual Production Contexts}

On their discursive practices, when dealing with the proposal of the Integrated Curriculum for Nursing Undergraduate Program, social actors elucidate aspects that involved the choice:

This integrated curriculum come to substitute the $p B L$ curriculum done by the University in 2007 for medicine and nursing... eh:: the campus is new, it was created by REUNI and EXPANDIR and has as commitment with o $M E C$ to increase the offer of spots in the region we are inserted through implementing courses with innovative eh:: curricula [...] and in 2008 when we arrived they were already done and we had to ONLY put into practice, we didn't participate in the construction, there wasn't space for discussion (P8).

When describing adherence to REUNI and to EXPANDIR, it is put on schedule the influences of micropolitic elements of national programs in teaching institution spaces, delineating the modus operandi of undergraduate courses. Associated to the understanding of the initial proposal as an answer for the commitment firmed with MEC, there is the highlight for conducting a curricular proposal which teachers didn't participate in the creation. 
Since the begining there was an insatisfaction with the curriculum through PBL from the students, as well as the teachers, we didn't feel it was possible, we didn't feel it was ours. We didn't know how to work with PBL, students were resistent and afraid of the type of training they were receiving and so were we $(P 8)$.

Teacher's resistance as for the proposed curriculum is reinforced in P8's discourse through the repetive use of the negation adverb "NO" and when finalize the narritive highlighting that "[...] students were resistent and afraid [...] and so were we". The teacher highlights the lack of participation of teachers in the process of curriculum construction and indicates that the curriculum goes through a process of teacher legitimation that leads to a reinterpretation of curricular policy and, often, to the creation of a new training course.

To construct and operate a new curricular proposal, there's the begining of a trajectory for elaborating of the current Undergraduate Nursing curriculum, which was permeated by a collective movement of (re)constructing teaching knowledge and experiences associated to (re)interpretation and (re)signification of education and health legislations and other institutions' curricula:

In 2008 we studied about how it was to build an integrated curriculum, which is the essence of this curriculum [...] We were in touch with laws... LDB, curricular guidelines, laws that regulate the SUS, government programs VER-SUS, PRÓ-SAUDE and some materials that treated higher teaching as, for exemple, Delors' report [...]So the year of 2008 was very intense... to construct a new curriculum, OUR current curriculum, we had few consulting, actually MANY consulting, there were several workshops (P8). [...] We discussed the documents that say how we should train the nurse and other pedagogical projects such as the University of Londrina, of Marilia [...] (P9).

When analyzing textual elements that compose PPC, it's perceived that it was created, in the Textual Production Context, in the midst of a movement of Influence Context recontextualization of elements, such as national education and health policies, theoretical cnceptions of integrated curriculum and experiences of other institutions. In their discourses, through intertextuality, the teachers refer to national and international documents, associated with the experiences of other universities, revealing that all these "voices" that compose the documents were reinterpreted and resigned to meet the expectations of the course and also to their expectations represented by the use of "OUR" in dealing with the curriculum.

If by one hand the movement of recontextualization brought alignment PCC with macropolitical elements that compose curricular policies of the undergraduate nursing program, by the other it highlighted different perpectives related producing a dispute, negociation and reinterpretation field which ended up configurating some weaknesses, as P8 highlights.
[...] there's a better part, one that's sort of oke another that went off tracks because we couldn't construct everything following the same logic... it's a very different curriculum from the traditional curriculum and great part of the teachers that arrived after 2008 didn't have the knowledge and ended up proposing unaligned modules (P8).

Documentary analysis of PPC reinforces discoursive practice of $\mathrm{P} 8$, when revealing, from the curricular matrix analysis and disposition of integrated modelu, fragilities on the curricular proposal related to: absence of cross-sectional themes, choice of specialities themes to conduct the axis of integration in the modules and excessive quantity throughout the curriculum, which favours the resumption of fragmented teaching, once the totality of the teaching process presents itself cutted in 41 modules.

\section{Practice Context: recontextualization of Curriculum for the teaching pratice}

On the practice context, it is observed that the curriculum, when translated by the teacher on the teaching and learning process, has it's principles effected from teaching practic $\mathrm{PTSCl}$, the planning of their classes and their understanding of what the integrated curriculum is. On PPC of the investigated curriculum, the adoption of the integrated curriculum as a curricular policy is supported by the curricular principles: relation theory and practice, teaching-service-community integration and interdisciplinarity. These principles, when translated by the teacher on his practice, enter in a movement of recontextualization of the elaborated curriculum on the interlocking of the Influence Context and Production Textual Context.

In the field of teaching practice, on the curricular unit $\mathrm{PTSCl}$, it is observed that the teachers, in their classes, establish among them, the knowledge and the students different modes of interaction that have implications in the effectiveness of the curricular principles. It was found on observed classes on PTSCI three modules of interaction among the teacher, student and knowledge, to know: QuestionListen - Inform (Q-L-I), Question-Listen-Dialogue (Q-L-D) and Question-Listen-Problematize (Q-L-P). These modes offer a perspective about the relationship the teacher stabilish when translating curricular principles that sustain the undergraduate Nursing Program integrated curriculum for the teaching and learning process.

The first pattern of interaction, Question- Listen - Inform (Q-L-I), is present in five of seven classes of PTSCI, making a total of 13 episodes. On the interaction Q-L-I, the teacher questions the student about theoretical and practical subjects of other curricular units, listens to the student, informs about theoretical and practical subjects of other curricular units and doesn't allow dialogue to happen. Teachers, in general, relate subjects that compose curricular units and information of these subjects constitutes the conductive thread of the interaction that teachers stabilish with students, as observed on PTSCISB 
The teacher informs students that theoretical subject of genogram and echomap will be worked on curricular unit PCT but that can be necessary on PTSCI, he will do an approach of main points. Following it, he asks: What is a genogram? Students answer in short sentences the definition. Without exploring the student's answers, he brings information ready of what is a genogram. Following up, he asks: What should we ask to construct a genogram? A student speaks the items to be questioned. The teacher listens to the student and immediately asks: what should we collect on medical records? The teacher, without waiting for an answer, inform items to be collected and follows the question: what is an echomap? A student says: it's collecting data about the family's social life. The teacher listen to the stuedent and informs the concept of echomap. Following, students and teacher go to visits (Observation note - PTSCI SB - Episode 03).

On interaction with students, teachers institute an intergame of questions and answers, to which three procedures are adopted: (I) the teacher asks, listens to the answer without exploring it and complements it with the ready concept; (II) the teacher asks, listens to the answer and immediately introduces a new question; and (III) the teacher asks and doesn't wait for the answer, bringing readiness and imprinting the questions a functional and instrumental character. It is observed that questions are used for information of subjects considered, by teachers, as necessary for activities proposed on PTSCI.

As for curricular principles, it's verified that on the interaction Q-L-I, among subjects approached by teachers, are those already aprehended in the classroom and also new knowledge. Teaching situations experienced on PTSCI are considered an arrival point on application of previous knowledge and a starting point on learning new subjects, favouring the relationship between theory and practice forseen on PPC. Relating to integration of teaching-service-community, interacting with students, teachers inform about subjects of diverse curricular units and signal the use of these knowledge on activities proposed on PTSCI. However, they don't make explicit relationships between teaching activies proposed for students and the reality of health services and community which students are inserted, compomising the integration among teaching, service and community indicated on PPC.

And, finally, relating integration of subjects, on interaction Q-L-I, teachers, when take the students to mobilize different curricular units' subjects to meet activites experienced on PTSCI, don't make interactions among them explicit. Comes from it a mobilization of subjects of diverse curricular units to meet activities of PTSCI, but are not favoured and explicit on interaction among them, signaling a multidisciplinar relationship of subjects.

The second pattern of interaction Question - listen dialogue (Q-L-D) was found in six of seven classes observed on PTSCI, consolidating a total of 19 episode. In the Q-L-D interaction, the teacher questions the student about theoretical and practical subjects of other curricular units; listens to the student and dialogues about theoretical and practical subjects of other curricular units, from informations translated by the student. Teachers resume theoretical and practical subjects of several curricular units. In the process of retrieving different subjects, the teachers support their practices in the movement of listening and dialoguing with the student. The conductive thread is the dialogue, as observed in episode observed on PTSCI TC:

The teacher tells students that a home visit is planned and asks: How should a home visit be? After listening to the students and consideration that this subject was already aprehended in previous semesters, the professor says they are correct in relation of steps of home visits and highlights it happens in diverse moments of the and that the intention is to make it each time more completed, considering the moment experienced by the student and the need of an integral assistance. Following it, the teacher calls a community health agent, that reports about a family to be visited. After the report, the teacher asks the students to get guidelines that will conduct the activities at home and discusses questions raised by students. The teacher listens to reported difficulties on applying the guidelines and puts oenself as support for the students on the visit (Observation note - PTSCI TC - Episode 01).

On interaction, the process to listen to students interfere on pedagogical action. This fact is observed when teachers, starting from discourses of insecurity of stusents, seek to supply doubts referred to subjects that compose activities of PTSCI. This way, listening is considered a dynamic with the other, in it's cognitive and affective dimension.

When questioning and discussing activities developed on PTSCl, teachers favour mobilization of previous knowledge of students and it's application on activities. The relationship theory and practice of subjects is favoured. The interaction teaching, service and community is favoured when teachers and students discuss the application of subjects that compose Nursing practice, considering informations of professionals that act on services and particularities of users. As for integration of subjects, there is a relationship between diverse curricular units, becoming it's applications clearer and more complementary. In this case, the relationship between curricular units subjects is favoured on discussions pointed a directing of pluridisciplinarity.

The third and last pattern of interaction presents as a chain sequency Question - Listen - Problematize (Q-L-P). On PTSCI, interaction chain $\mathrm{Q}-\mathrm{L}-\mathrm{P}$ was present in three episodes, being one observed episode on PTSCI PB and two observed on PTSCIWN. On interaction $Q-L-P$, the teacher questions the student about theoretical and practice subjects of other curricular units, listens to him e problematize with him soluctions for identified problems. In this interaction, teachers conduce a relationship between them and the students from problematization of situations experienced 
on PTSCl. Problematization developed by teachers has a starting point ideas and feelings that emerged from teaching situations and realities experienced on PTSCI, as observed on PTSCI WN:

The nurse from the sector informs that there is a prescription of bladder catheter (BC). The teacher explains the technique from different curricular units subjects and say that students have previous knowledge that enables them to put the bladder catheter. He highlights that, even though it is a procedure still not experienced on it's specificity, knowledge were already approached in the course. He highlights the importance of putting a catheter and assumes the support role on the technique. The teacher cites the next step at the end of an action and the students put in the catheter. At the end of it, the teacher asks: For you, how it was to put a catheter? How did you feel? Students talk about the perception of previous knowledge and feelings of fer, insecurity and anxiety. The teacher, after listening to the students, says that the fear of new is natural, specially in situation that involves assisting the other. However, fear and insecurity can be minimized when we have the opportunity to reflect about what we are going to do about the assistance of other, because this allows us to recognize recognize the knowledge we have about the technique or the problem to be solved and, this we have a bigger chance of make the right decision. [...] (Observation Note - PTSCI WN Episode 05).

Teachers, anchored on students' subectivity, takes us to talk about their feelings and experiences on PTSCl and to reflect about knowledge and attitudes that permeate the exercise of practice of Nursing. This process happens when teachers and students dialogue about the application of several knowledge that compose the practice of Nursing considering caring for the other an exercise of the profession. It comes from there the favourable moment to integrationg among teaching, service and community.

By fostering dialogue and reflection on and from the experiences of PTSCl, teachers allow students to perceive that the contents learned in the curricular units can be mobilized and articulated in the conduct of the activities developed in the PTSCl. As for integration of subjects, teachers overcome the dichotomy theory and practice when they allow students to live teaching situations in which theoretical and practical knowledge interpenetrate. The teachers lead the students to mobilize their previous knowledge and, in the face of this movement, lead them to articulate and build new knowledge necessary for the activities proposed in PTSCI.

It is verified that there is not an isolated and specific movement for the use of the contents of the curricular units in the situations of teaching lived by teachers and students. There are situations where the practice of Nursing is practiced in which the different knowledges are seen as interdependent, favoring the overcoming of the boundaries between the curricular units, pointing to an interdisciplinary relation of the subjects.

In the field of teaching planning, the teachers elaborate their intentions for the teaching practice based on notions of the teacher, knowledge and student interaction in which the emphasis is on the transmission of information, the dialogue and the problematization. In this circumstance, teachers, in general, propose directions to their classes based on more than one notion of interaction. The notions of interaction as the dialogue are those that appear most in the discourses, sometimes associated with information, sometimes with the problematization and now associated to both.

When opt by the notion of information transmission, the teachers justify it considering the difficulty of the student to integrate and the need to introduce new contents or to return to those already apprehended for the accomplishment of the activities in the PTSCl.

[...] There are moments that we have to be more traditional, there are knowledge that in that moment the student can't integrate, so I bring the subject, what he needs to know for PTSCI [...] (P3). [...] I speak about subjects I consider important because like this... sometimes the student can't realize, doesn't know and we have to teach $(P 7)$.

In proposing the dialogue, they consider that these moments favor the relationship between the theoretical and practical subjects and bring the students closer to the health services, the reality found and the practice of Nursing.

\begin{abstract}
On PTSCI... it's a moment I am able to realize the student have already learned and how I can help him on this construction [...] I am exploring the possibilities of integration [...] I try to get the students to speak, present their knowledge so that we can integrate together and discuss the practice scenario [...] is a dialogic relationship with him, of trying to make him more active in this teaching-learning process [...] (P2).
\end{abstract}

Concerning the problematization, it is observed that this proposal happens when the teachers consider the experiences lived in the PTSCl as a strategy for the (re)construction of knowledge with and by the students and for the reflection on the situation experienced.

[...] there are moments, mainly in practice, that enables to happen something different... inovative... which is the moment of that situation that was experienced on PTSCI. We have the possibility to reflect on the moment lived in the PTSCl and to bring different elements that make up that context there [...] (P5). 
When treating understandings of teachers about the Integrated Curriculum, it is perceived that to define them teachers construct their discursive practices in a tangle of interdiscourses and intertexts that make up the traditional and integrated curriculum:

Well... I think it's a very different curriculum from the traditional one [...] there is not a basic cycle and after a profissionalizating one, these two cycles happen together and during the whole course (P1). [...] it is one that brings as a pedagogical presupposition the integration of knowledge (P2). [...] the practice, it is the goal for the construction of the curriculum itself and for the construction of teaching practice, it is logical that this is a challenge because of our construction in the professional and teaching more in the traditional teachingal [...] (P5). [...] is a curriculum that seeks to train professionals who can work in SUS and who have the professional profile as it is in the curricular guidelines for nursing (P6).

In the conceptual field, teachers, when refer to the integrated curriculum, stabilish a movement of articulation of discourses related to the traditional curriculum and to the integrated curriculum, in which, through denying traditional teaching, seek to sustain the concept of integrated teaching. For teachers, the integrated curriculum brings challenges to their practices, considering that it requires different teaching methods, contrasting their professional experiences and teachers built from traditional curricula.

Teachers understand that the integrated curriculum seeks to overcome the separation between the basic and professional cycle, favoring the theory-practice relationship and the subjects integration. They also consider that it brings the student closer to the reality of the health services and attends to the training provided for in the NCG and to work in the SUS, besides presupposing a student-centered teaching and the joint construction of knowledge based on the teaching situations experienced.

\section{DISCUSSION}

It is verified that curricular policies when being forged bring for guidelines elements that compose educational policies in the international and national territory, which in varying degrees exert influences on the direction to be given in the proposition of a curriculum. ${ }^{21}$ Understanding the process of producing an educational policy brings to light the possibility of understanding the meanings that are negotiated and legitimized in the macro and micropolitical spaces for curricular policies in a given circumstance. ${ }^{21}$

In this analysis it is noticed that PPC was woven in the Textual Production Context in the midst of a bricolage movement, ${ }^{21}$ that is, a kind of recontextualized copy ${ }^{21,23}$ of components of CG/ENF, of health policies, of theoretical concepts of integrated curriculum, of experiences of other teaching institutions and of guidelines for Higher Education. It follows from this that a curriculum that has brought learning and integration of different knowledges, the redirection of teaching methods and the gathering of arguments of globalization, interdisciplinarity, socioeconomic interrelationships ${ }^{6}$ and preparation for lifelong learning. ${ }^{3}$ Studies that analyze health education and the curricular proposals show that the option for the integrated curriculum has become a frequent reality in recent years ${ }^{18,26-27}$ to be seen as favorable to the professional and social perspectives for the 21 st century foreseen in national ${ }^{9}$ and internacional ${ }^{3}$ policies.

The textual analysis of the PPC also reveals that the (re)interpretation movements of references about integrated curriculum and other curricular experiences have brought weaknesses for the implementation of the curriculum that resemble the results of a study ${ }^{28}$ in which it was found that the increase in the number of integrating modules, associated with the difficulties of teachers to work without subjects of their specialties, compromised the integrated organization, interdisciplinarity and the inseparability of theory and practice.

When being translated for the Practice Context, it is verified that the curricular policies are also subject to be recontextualized by those who make up the micropolitical spaces, especially the teachers. ${ }^{21}$ In this field, curricular policies take shape and take their place in the educational process according to the diverse experiences, values and interests that teachers bring to their social practice, which gives them authorship on curricular policies when they are (re)produced. ${ }^{21}$

In the Practice Context, the integrated curriculum has been recontextualized by the teacher between the conduction of his practice in the classes, his planning and his understanding of the integrated curriculum. In all dimensions, the interactions between teacher, knowledge and student fall into notions of information transmission, dialogue and problematization.

In general, it is observed that teachers, even recognizing the curricular principles and the potentialities of the integrated curriculum, do not rely exclusively on these understandings to conduct their classes, since they return to elements of traditional teaching by valuing the transmission of information. In their planning, while expressing positions that point to the concretization of problematizing practices, when they translate their intentions into the field of action, they are redirected to the transmission of information associated with the dialogue.

The teachers' movement of articulation between discourses related to the integrated and traditional curricula denotes that the integrated curriculum is a place of reference co-inhabited by the place of reference of the traditional curriculum, each one with its instruments and its ways of dealing. ${ }^{29}$ This shows the recontextualization of the curriculum anchored in the experiences and in the formative processes of the teachers. This condition is manifested by the important presence of the transmission of information in the choices and the actions of the teacher, even if, in most cases, it is associated with dialogue and, at certain moments, with dialogue and problematization. 
It is noted that the practice of the integrated curriculum has been experienced to some extent by teachers. However, elements of the traditional curriculum are still present as references to teachers. Thus, the traditional curriculum is a limiting factor for the realization of the integrated curriculum, since the two conceptions of curriculum (traditional and integrated) are in "dispute" in the daily life of the teachers, with a view to the hegemonization of one of them. It is a breakthrough movement with the hegemony of traditional teaching practices that were and are often still the only pedagogical conception recognized and experienced by the teacher.

These findings are similar to the results of other studies, ${ }^{28-30}$ in which teachers of undergraduate health courses, although they recognize the role to be played, lead their practice in the traditional parameters, privileging the transmission of knowledge. Other studies that evaluate changes in teaching practice and adherence to active methodologies also show that teachers, even teaching in innovative curricula, develop their practice linked to the old models and the way they have learned. ${ }^{31,32}$ The implementation of the integrated curriculum by teachers implies changing the crystallized territories of knowledge, the identity of the social actors involved and their practices, considering that the translation of the PPC into teaching practice is through its personalization in teachers. ${ }^{33}$ In the translation of the integrated curriculum there is an adaptation process, the result of which is not copying but the recontextualization of the curriculum, aligning it with the experiences and values of the teacher. ${ }^{34,18}$

The curriculum is always in the process of becoming, and can be (re)interpreted and (re)meaning constantly, because, in the Practice Context, the experiences and the knowledge of the teachers become elements of the mediation of the curriculum prescribed in the PPC and that lived in the process of teaching and learning.$^{34}$ Starting from the processes of recontextualization present in the curriculum of the Nursing Undergraduate Program and seeking to see them beyond the difficulties in the curriculum implementation, it is understood that the reinterpretation and resignification movements also reveal possibilities of recreations that do not make up the universe of the elaboration of the PPC,$^{34}$ but from the experiences of the Practice Context. These movements of recontextualization do not always happen in the perspective of distancing from the curricular principles; they should be seen as a possibility for the emergence of new and (re)creations in and of curricular policy.

\section{FINAL CONSIDERATIONS}

It is verified that the aim of analyzing the recontextualization process of the Integrated Curriculum of the Nursing Undergraduate Program was reached, although the corpus of this study was restricted to the teachers of the PTSCI course unit. It is believed that the recontextualization of the curriculum also occurs in important proportions in the other curricular units that make up the curriculum. However, the analysis from the PTSCl allowed us to demonstrate that the process of recontextualization in and between the contexts of Policy Cycles implies a curriculum that is the result of a process of bricolage of education policies, health policies and the experiences of other institutions.

It was verified that there are weaknesses related to organization of modular structure and lack of teacher's approximation with the Textual Production Context which, associated to the teaching training and the previous experience of traditionl teaching, favour reinterpretation of the curricular proposal when it's translated for the Practice Context. It is necessary to institute strategies that interact the teaching training to the quotidian of curricular policies, once teachers are the main social actors on concretization of a curriculum nd determined of new pathways.

\section{REFERENCES}

1. Pereira EMA, Heinzle MRS, Pinto MM. Internacionalização na educação superior e mobilidade estudantil: o vai e vem de jovens acadêmicos. Rev Esp Pedag [Internet]. 2017 Jan/Apr;24(1):35-49. Available from: http://seer.upf.br/index.php/rep/article/view/6990

2. Pereira EMA. Pedagogia universitária para novas clientelas estudantis. Rev Argentina Educ Superior [Internet]. 2017;9(14):113-29. Available from: http://www.revistaraes.net/revistas/raes14_art5.pdf

3. Unesco. United Nations Educational, Scientific and Cultural Organization. World Conference on Higher Education: the new dynamics of higher education and research for societal change and development. Paris: Unesco; 2009. [cited 2015 Dec 10] Available from: http://unesdoc.unesco.org/images/0018/001892/189242e.pdf

4. Siqueira-Batista R, Gomes AP, Albuquerque VS, Cavalcanti FOL, Cotta RMM. Education and competences for the Brazilian Unified Health System (SUS): is it possible to find alternatives to the logic of late capitalism? Ciênc Saúde Coletiva [Internet]. 2013 Jan;18(1):159-70. Available from: http://www.scielo.br/scielo.php?script=sci_arttext\&pid =S1413-81232013000100017

5. Cruz E, Costa FA. Revisitando o(s) sentidos para a Integração Curricular. Rev e-Curricul [Internet]. 2015 Apr/Jun;13(2):193-213. Available from: https://revistas.pucsp.br/index.php/curriculum/article/ view/21875

6. Santomé JT. Globalizacion e interdisciplinariedad: el curriculum integrado. Madrid: Ediciones Morata; 2012.

7. Rodrigues J, Zagonel IPS, Mantovani MF. Alternativas para a prática docente no ensino superior de enfermagem. Esc Anna Nery [Internet]. 2007;11(2):313-7. Available from: http://www.scielo.br/scielo. php?script=sci_abstract\&pid=S1414-81452007000200020\&Ing=pt\& $\mathrm{nrm}=$ iso

8. Oliveira IC, Cutolo LRA. Health Science Students' Views on Comprehensiveness. Rev Bras Educ Med [Internet]. 2015 Apr/ Jun;39(2):208-17. Available from: http://www.scielo.br/scielo. php?script=sci_arttext\&pid=S0100-55022015000200208

9. Teixeira E, Fernandes JD, Andrade AC, Silva KL, Rocha MEMO, Lima RJO. Overview of Nursing Graduation courses in Brazil in the National Curriculum Guidelines decade. Rev Bras Enferm [Internet]. 2013 Sep;66(no.spe):102-10. Available from: http://www.scielo.br/scielo. php?script=sci_arttext\&pid=S0034-71672013000700014

10. Ministério da Educação e Cultura (BR). Conselho Nacional de Educação Brasil. Câmara de Educação Superior. Resolução CNE/CES № 03 de 07 de novembro de 2001. Diretrizes Curriculares Nacionais do Curso de Graduação em Enfermagem. Brasília (DF): Diário Oficial da União; 2001.

11. Fernandes JD, Rebouças LC. A decade of National Curriculum Guidelines for Graduation in Nursing: advances and challenges. Rev Bras Enferm [Internet]. 2013 Sep;(no.spe):66:95-101. Available from: http://www.scielo.br/scielo.php?script=sci_arttext\&pid $=$ S0034-71672013000700013 
12. Soriano ECl, Peres CRFB, Marin MJS, Tonhom SFR. Os cursos de enfermagem frente às diretrizes curriculares nacionais: revisão integrativa. Rev Enferm UFPE On Line [Internet]. 2015 Apr;9(Suppl. 3):7702-9. Available from: https://periodicos.ufpe.br/revistas/ revistaenfermagem/article/viewFile/10511/11389

13. Chaves SE. Macropolitical and micropolitical movements in the undergraduate teaching on nursing. Interface (Botucatu) [Internet]. 2014 Apr/Jun;18(49):325-36. Available from: http://www.scielo.br/scielo. php?script=sci_arttext\&pid=S1414-32832014000200325

14. Varela DSS, Carvalho MMB, Barbosa MUF, Silva IZF, Gadelha RRM, Machado MFAS. Diretrizes Curriculares Nacionais e a Formação de Profissionais para o SUS. Rev Bra Educ Saúde [Internet]. $2016 \mathrm{Jul} / \mathrm{Sep} ; 6(3): 39-43$. Available from: http://oaji.net/ articles/2017/2628-1515417342.pdf

15. Kloh D, Reibnitz KS, Lima MM, Correa AB. Changes in nurses training under the axis of comprehensive care: integrative review. Rev Enferm UFPE On Line [Internet]. 2014 Jan;9(Suppl.1):475-83. Available from: https://periodicos.ufpe.br/revistas/revistaenfermagem/article/ view/10361

16. Galindo MB, Goldenberg P. Interdisciplinaridade na Graduação em Enfermagem: um processo em construção. Rev Bras Enferm [Internet]. 2008;61(1):18-23. Available from: http://www.scielo.br/scielo. php?pid=S0034-71672008000100003\&script=sci_abstract\&tlng=pt

17. Teófilo TJS, Santos NLP, Baduy RS. Betting on change in medical education: trajectories of a medical school. Interface (Botucatu) [Internet] 2016 Jan/Mar;21(60):177-88. Available from: http://www.scielo.br/scielo. php?script=sci_arttext\&pid=S1414-32832017000100177

18. Garanhani ML, Vannuchi MTO, Pinto AC, Simões TR, Guariente MHDM. Integrated Nursing Curriculum in Brazil: A 13-Year Experience. Creative Education [Internet]. 2013;4(12):66-74. Available from: https://file.scirp. org/pdf/CE_2013123015545951.pdf

19. Heinsle MRS, Bagnato MHS. Recontextualização do currículo integrado na formação médica. Pró-Posições [Internet]. 2015 Sep/Dec; [cited 2016 May 10]; 26(3):225-38. Available from: http://www.scielo.br/pdf/ pp/v26n3/0103-7307-pp-26-03-0225.pdf

20. Pierotti I, Pinto AC, Moraes FR, Garanhani ML. Currículo integrado de Enfermagem: distribuição e avaliação do tema transversal ser humano. Rev Espaço Saúde [Internet]. 2014;15(Suppl 1):175-84. Available from: https://docplayer.com.br/71826092-Curriculo-integradode-enfermagem-distribuicao-e-avaliacao-do-tema-transversal-serhumano.html

21. Ball SJ, Bowe R, Gold A. Reforming Education \& Changing SchoolsCase Studies in Policy Sociology. London: Routledge; 1992.

22. Bagnato MHS. Recontextualização curricular no ensino de Enfermagem. Curr Front [Internet]. 2012 Sep/Dec;12(3):173-89. Available from: http:// www.curriculosemfronteiras.org/vol12iss3articles/bagnato.pdf
23. Bernstein B. A estruturação do discurso pedagógico: classe, códigos e controle. Petrópolis: Vozes; 1996.

24. Yin RK. Estudo de caso: planejamento e métodos. Porto Alegre: Bookman; 2015.

25. Fairclough N. Discurso e Mudança Social. Trad/Org. Izabel Magalhães. Brasília: Universidade de Brasília; 2016.

26. Ide CAC, Arantes SL, Mendonça MK, Silva VR, Del Corona ARP. Avaliação da implantação do currículo integrado no programa de graduação em enfermagem. Acta Paul Enferm [Internet] 2014;27(4):340-7. Available from: http://www.scielo.br/pdf/ape/ v27n4/1982-0194-ape-027-004-0340.pdf

27. Pereira WR, Chaouchar SH. Identificação de novas práticas pedagógicas na percepção dos docentes de um curso de enfermagem. Ciênc Cuid Saúde. [Internet]. 2010 [cited 2016 May 10]; 9(1):99-106. Available from: $\mathrm{http}: / /$ periodicos.uem.br/ojs/index.php/CiencCuidSaude/ article/view/10533/5742

28. Alves E, Burgatti JC, Oliveira MAC. Um olhar hermenêutico-dialético sobre alterações curriculares de um curso graduação de Enfermagem. Invest Qualitat Saúde [Internet]. 2014;2:23-6. Available from: https:// proceedings.ciaiq.org/index.php/CIAIQ/article/view/428/425

29. Franco ECD, Soares AN, Bethony MFG. Currículo integrado no ensino superior em Enfermagem: o que dizem os enfermeiros docentes. Enferm Foco [Internet]. 2016;7(1):33-6. Available from: http://revista.cofen.gov. br/index.php/enfermagem/article/view/662/281

30. Freitas DA, Santos EMS, Lima LVS, Miranda LN, Vasconcelos EL, Nagliate PC. Teachers'knowledge about teaching-learning process and its importance for professional education in health. Interface (Botucatu) [Internet]. 2016 Jan; [cited 2017 Feb 10]; 20(57):437-48 Available from: http://www.scielo.br/scielo.php?script=sci_arttext\&pid $=$ S1414-32832016000200437

31. Mesquita SKC, Meneses RMV, Ramos DK. Metodologias ativas de ensino/aprendizagem: dificuldades de docentes de um curso de enfermagem. Trab Educ Saúde [Internet]. 2016 May/Aug; [cited 2017 Jan 10]; 14(2):473-86. Available from: http://www.scielo.br/pdf/tes/ v14n2/1678-1007-tes-1981-7746-sip00114.pdf

32. Vieira JE, Tamousauskas MRG. Evaluation of Faculty Resistance to Proposals for Renovation in Undergraduate Medical Curriculum. Rev Bras Educ Med [Internet]. 2013; [cited 2017 Feb 3]; 37(1):32-8. Available from: http://www.scielo.br/pdf/rbem/v37n1/05.pdf

33. Sacristan JG. Aproximação ao conceito de currículo. In: Sacristan JG, eds. O currículo: uma reflexão sobre a prática. Porto Alegre: Artmed 2017.

34. Bethony MFG, Souza V, Soares AN, Franco ECD, Souza RS, Oliveira VAC. Nursing curriculum evaluation: crossing into the educational Project. REME Rev Min Enferm [Internet]. 2016; [cited 2017 Mar 10] 20:e962. Available from: http://www.reme.org.br/artigo/detalhes/1097

\footnotetext{
${ }^{a}$ Article derived from the Doctoral's Degree Thesis entitled "The recontextualization of the integrated curriculum of the Nursing Course of the Federal University of São João Del Rei", presented in the Postgraduate Program in Nursing of the Federal University of Minas Gerais, 2016.
} 